\title{
The New Scottish Renaissance?
}

\author{
Scott Hames
}

for Peter Boxall and Bryan Cheyette (eds), The Oxford History of the Novel in English: Volume 7, British and Irish Fiction Since 1940 (Oxford University Press, 2016)

https://global.oup.com/academic/product/the-oxford-history-of-the-novel-inenglish-9780198749394?cc $=\mathrm{gb} \&$ lang $=\mathrm{en} \&$

In his judicious but untimely survey of the Scottish novel, Francis Russell Hart observed that 'a distinctive feature of modern Scotland's literary establishment has been its hostility to, or relative lack of interest in, the novel as a form' (Hart 1978, p. vii). Poetry was the medium of the nationalist literary renaissance of the 1920s-30s, and its dominant figure, Hugh MacDiarmid, had 'frankly and influentially expressed the view that the novel is an inferior kind of literary expression, that "prose" is "noncreative"" (vii.). But from the revivalist perspective the real failing of modern fiction was not generative but recuperative. The territory of the novel was off-limits to cultural revival of MacDiarmid's kind, being impervious to the willed recovery of latent nationality. 'The trouble with nearly all modern Scottish literature', he wrote in 1946 , is that

it deals with the past, with pre-Industrial-Revolution times or with rural areas where 'the old ways' to a large extent continue. But as soon as it tackles urban problems and the conditions and prospects of modern life it peters out. This is because we have no writer yet big enough to carry over the independent Scots literary tradition from the bucolic and non-industrialised milieu in which it flourished into the contemporary scene. (MacDiarmid 1968, p. 159)

\footnotetext{
${ }^{1}$ The towering exception here is Lewis Grassic Gibbon's trilogy of novels A Scots Quair (1932-34), though it should be noted Gibbon's blend of communism and nationalism is in the reverse proportion of MacDiarmid's, and was actuated by a quite different (paleo-anarchist) notion of freedom. Indeed, the Quair itself figures the urban, class-conscious world of Grey Granite (volume 3) as devoid of the authentic (and symbolically national) preindustrial community elegised in the much better-loved Sunset Song (volume 1).
} 
Notice that Scottish writing 'peters out' in the city not for any lack of modern experience to explore, but because its idiomatic Scottishness cannot be 'carried over' onto the terrain of the novel and remain authentic - that is, authentically rooted in an independent cultural tradition. Add the reality of industrial deracination - the fact that 'there is little that is positively Scottish in the life of the modern cities, Glasgow, Edinburgh, or that distinguishes them from other cities of the modern world' (Speirs 1962, p. 154) - and there seems little prospect of a 'national' revival in the art of the novel.

Yet the period since Hart's 1978 study is now regarded as a golden age of Scottish fiction, especially the novel of alienated urban experience. This chapter examines the genuine boom in Scottish literary fiction during the 1980s and -90 s, and the rhetoric of its presentation as a 'new renaissance'. With this label came remarkably strong claims for the political efficacy of the contemporary literary novel, a phenomenon that has not attracted the interest it deserves from literary historians outside Scotland. In the two decades prior to devolution, the emergence of formally ambitious Scottish novelists including Alasdair Gray, James Kelman, Iain Banks, A.L. Kennedy, Irvine Welsh, Janice Galloway, Andrew O’Hagan and Alan Warner sponsored a conflation of fiction and democracy which figured the novel as the locus of national selfrepresentation and re-invention - as Scotland's 'real' parliament prior to, and in some sense leading to, the establishment of Holyrood in 1999. While there is clear evidence of these writers' influence on the self-image of post-devolution Scotland, a closer examination of their fiction and its staging of 'Scottishness' complicates any straightforward affiliation with cultural nationalism. ${ }^{2}$ The 'new renaissance' discourse, I will suggest, both inflates the social impact of these novelists and delimits the politics of their writing to the display of suppressed 'identity'.

In re-reading the novels most often grouped under this term it is striking how little they deliver the confident national affirmation 'new renaissance' would seem to imply. As a leading nationalist critic admitted at the time, 'we are faced with the

\footnotetext{
${ }^{2}$ See, in Hames 2012, the stated views of many writers cited in this chapter (directly addressing the September 2014 referendum on Scottish independence). Arguments for independence but against nationalism were not uncommon during the referendum debate, especially on the 'cultural' left.
} 
paradox of what looks like a revival of Scottish writing, but the theme of which is pessimism about the very events the revival describes' (Gifford 1990b, p. 11). 'If we are witnessing a new "renaissance",' Douglas Gifford observed, 'its subject matter is predominantly the dearth of real culture and aesthetic freedom in modern Scotland' (Gifford 1990a, p. 2). A painful ambivalence clings to the 'new renaissance' from the very start. In 1989 the German critic Peter Zenzinger observed that

contemporary life as depicted by Scottish writers has very few alluring traits [...] all the zest has gone out of life, all prospect of a better life has withered. This complaint is familiar enough in all industrialized countries, and yet the extreme bitterness with which it is uttered in Scottish writing is remarkable. (quoted in Wallace 1993, p. 219)

The uplift of this narrative is rooted in political despair. 'It is tempting', Gifford notes in retrospect, 'to see [the] change of confidence' in 1980s Scottish fiction 'as somehow related to the 1979 Devolution referendum and the growing assertion of Scottish identity and its varieties that emerged almost in defiance of that quasidemocratic debacle' $\left(2007\right.$, p. 237). ${ }^{3}$ Quickly succumbing to this temptation, a dynamic, quasi-constitutional role for Scottish fiction is asserted:

Scottish fiction approached the millennium as a standard bearer for Scottish culture, arguably even supplying the most successful explorations of changing Scottish identities, in a rich variety of voices and genres. The new complexities in novelistic vision relate dynamically to the changes taking place in Scottish society at large, not only reacting to them, but influencing the framework of thought in which they took place. (ibid.)

\footnotetext{
${ }^{3}$ The March 1979 referendum failed because a last-minute Conservative amendment to the bill required not only that the majority of voters should support the proposal for a National Assembly, but $40 \%$ of the entire electorate. The first condition was narrowly met (51.6\%); the second was not (32.9\%), triggering deep anger and pessimism among cultural activists. When the Callaghan minority government refused to accept the narrow Yes majority as sufficient warrant to implement devolution, the Scottish National Party withdrew its support, tabling a motion of no confidence the government lost 311-310. In the ensuing general election Margaret Thatcher's Conservatives were elected with a 44-seat UK majority, winning 22 of 71 Scottish seats. Conservatives were elected as 21,10 and 11 of 72 Scottish MPs in the general elections of 1983, 1987 and 1992 (respectively), and the democratic legitimacy of the Thatcher/Major governments in Scotland was questioned ever more loudly.
} 
This is a remarkable claim - in the age of television and global mass culture, literary novels supplying the 'framework of thought' in which a modern Western country reimagines itself - but it has been normalised by repetition. In 1998 Christopher Whyte argued that 'in the absence of elected political authority, the task of representing the nation has been repeatedly devolved to its writers' (p. 284). So effective were these unelected but hardly unacknowledged legislators, when the new parliament finally opened Liam McIlvanney was struck by 'how little it now seemed to matter'.

Its coming was welcome, certainly, but hardly seemed critical to the nation's cultural health. Above all, it was belated: by the time the Parliament arrived, a revival in Scottish fiction had been long underway [...] Without waiting for the politicians, Scottish novelists had written themselves out of despair. (2002, p.

Indeed, a 1999 issue of Edinburgh Review on the new parliament was quick to declare its redundancy, the writer Duncan McLean insisting 'there's been a parliament of novels for years. This parliament of politicians is years behind' (Edinburgh Review $100)$.

Alex Thomson traces the first appearance of this trope to Cairns Craig's editorial foreword to the Determinations series on Scottish politics and culture beginning in 1989: 'the 1980s proved to be one of the most productive and creative decades in Scotland this century - as though the energy that had failed to be harnessed by the politicians flowed into other channels'. The narrative of devolution as 'the metaphorical sublimation of political energy into literary production' is open to question, even before we consider the politics of the novels assimilated to this rubric (Thomson 2007). As Aaron Kelly points out, the culturalist reading of Scottish devolution takes for granted that 'it was the national question which preoccupied culture before devolution', during which period writers and artists 'were primarily engaged in proving their Scottishness' (2007, p. 175). It should hardly need stating that a long list of Scottish literary novelists were otherwise occupied during the 1980s and $90 \mathrm{~s}$, but I have chosen texts routinely located within the new renaissance in order to examine its internal dissonance. When we consider the formal and thematic 
commonalities among these novels, it could be argued that the radical forms of autonomy which with they are preoccupied - personal, psychological, linguistic - are traduced by the hasty nationalising of their political energies, or efforts to subsume their ethical stridency within the 'healthy polyphony' of national democratic fulfilment (see Kelly 2007). Encountered here as instantiations of The Scottish Novel, these texts can hardly be separated from the retailing of national display-identities associated with the new renaissance; I nonetheless attempt to set the politics of these texts within and against the terms of identitarian spectacle.

\section{Lanark: 'This is it'}

Whatever scepticism might attach to the rhetoric of the 'new renaissance', Alasdair Gray's Lanark: A Life in Four Books (1981) was a genuine watershed. As early as 1998, Alan Warner had grown 'very fed up with being bunched with that whole Scottish thing' (quoted by Ferrebe 2010, p. 9), but its role in his own development seems clear:

shortly after I started to read a great deal - when I was 15 and 16 - I saw a first copy of Lanark in an Oban art shop and actually turned to my friend and stated, 'So is there actually a Scottish person writing novels today, in Scotland?' [...] I had presumed novels were an art form which only happened elsewhere and had died out in Scotland around the time of Walter Scott. (Warner 2011, p. 13)

This jarring reversion is less eccentric than it first appears. As many editions of Lanark boast on the cover, Anthony Burgess dubbed Gray - on the strength of his first book - 'the best Scottish novelist since Sir Walter Scott'. That this line of national succession over-leaps almost the entire history of the modern novel is suggestive. 'It was time Scotland produced a shattering work of fiction in the modern idiom,' Burgess declared, comparing Lanark to Ulysses: 'This is it'. Seemingly, the writer 'big enough' to Scottish the novel had arrived. A realist Künstlerroman nested within a fantastical political allegory, drawing equally on Kafka, Blake and Dante, Lanark served as a new dispensation to writers of Warner's generation, but its function in proving the 'given' reality of the Scottish novel is at odds with its own 
passionate emphasis on aesthetic newness. The most oft-cited passage in all of modern Scottish literature, frequently presented as Lanark's core cultural 'message', concerns precisely the impasse between urban Scottish experience and any usable artistic tradition. The central character of the loosely autobiographical sections, Duncan Thaw, is smoking on a rooftop with his friend:

'Glasgow is a magnificent city,' said McAlpin. 'Why do we hardly ever notice that?' 'Because nobody imagines living here,' said Thaw. '[...] think of Florence, Paris, London, New York. Nobody visiting them for the first time is a stranger because he's already visited them in paintings, novels, history books and films. But if a city hasn't been used by an artist not even the inhabitants live there imaginatively. [...] Imaginatively Glasgow exists as a music-hall song and a few bad novels. That's all we've given to the world outside. It's all we've given to ourselves.' (Gray 2007 [1981], p. 243)

But this warrant to invent was soon revoked by the literary nationalism Lanark itself had galvanised. By 1996, Ian A. Bell argued that 'whatever Thaw or Gray might polemically claim, Scotland has probably by now been imagined often enough: the task for novelists writing today, on whom an enormous responsibility falls, is to begin to imagine it properly' (p. 222). This nationalist 'responsibility' signals the emerging impossibility of being critically recognised as a Scottish novelist in the absence of a commitment (or at least engagement) with the Kulturkampf with which Gray became identified, both in his fiction (self-designed editions were often adorned with the slogan 'work as if you live in the early days of a better nation') and in the polemic Why Scots Should Rule Scotland (1992; revised 1997, 2005). To grasp what happened in the intervening period, we must return to Francis Russell Hart and the relationship between the 'subject and the vehicle of expression' - Scottishness versus the novel.

The novel's general function as register of 'the distinctive psychological features of modern urbanization' (Watt 1987, p. 178) tends to impede the efforts of literary nationalists to preserve and renew the particularity of Scottish literary identity (above all, its un-Englishness). What is distinctive about urban individual experience - first novelised in England, and as English - is, by this model, antithetical to the distinctiveness of Scottish cultural tradition, rooted in a world before the novel, when 
the Scottishness of Scotland was more piquant and secure. Hart's attempt to 'identify distinctive motifs and methods in the novel that are reflective of Scottish origins and experience' (1978, p. ix) is vitiated by this opposition, and its subtending relationship between history and literary form. In the nationalist discourse established by MacDiarmid, fidelity to contemporary lived experience - the realist novel's usual claim to artistic value - is trumped by a cohesion model of national authenticity. A Scottish novel is one that transmits or refines some distinctive national form (e.g. balladic impersonality, narrative 'motifs and methods' such as psychological dualism), irrespective of whether its fictional doings and happenings reflect the experience of living national subjects. Defined by its genetic autonomy from a hazily defined Anglocentric mainstream, under this rubric only novels which have mastered and grafted into themselves the established topoi and shibboleths of literary Scottishness are legible as truly 'national'. And so the art form of the capricious, the circumstantial and the eccentric is restricted by its duty to include stalwart motifs, to affirm or contest received conventions of national character and national style, and to 'carry over' relics - above all, linguistic relics - of a more separate and communal past.

In the final decades of the twentieth century, the historical pattern underlying this dilemma took a new direction. Even if the 'Scottish novel' were a stable and flourishing national form, Hart argued in 1978, the dominance of British literary culture would tend to muffle and distort its significance.

Literary education in the universities has been dominated until recently by a classical English curriculum, and academic studies of the 'British novel' have found room for Scottish groups and movements only as provincial offshoots of English traditions. The inadequacy and irrelevance of such a perspective remain to be demonstrated. The demonstration, to be sure, is not made easier by the fact that the novelists themselves have often slighted or concealed linguistic or cultural nationality, or that when they have not done so, 'cosmopolitan' readers have labeled them provincial. The Scottish novelist's problem of audience is a real one, no less so than the related problem of linguistic nationality. (1978, p. viii) 
Such caution seemed unnecessary only a few years later. Hart took stock of the Scottish novel from within the terms of MacDiarmid's literary nationalism at precisely the moment political developments rendered its pet debates redundant. Between 1979 and 1997 Scottish identity acquired a very different political valence, and the 'inadequacy and irrelevance' of British-centred paradigms proved less controversial. Scotland's effective silencing in UK electoral politics provoked a crisis of democratic legitimacy and sub-nationalist dissent, such as Edwin Morgan's 1987 satirical poem in search of Westminster's 'Lost Mandate' to represent Scotland (1994, p. 8). By the mid-1990s 'linguistic nationality' had reversed polarity, shifting from an index of backwater localism to become the embodiment of edgy, urban, oppositional Scottishness, partly aligned with the nationalisation of class grievance in antiThatcherism. During this period the atomised Scottish city was transformed from a zone of cultural non-being to a privileged site of national injury. In the period of its dismantling, Lowland industrial civilization was elegised as a repository of national community defined by class solidarity and masculine self-respect, and destroyed by the imposition of 'alien' neoliberal values. An emergent register of vernacular Scottishness projected a national class speech as the embodiment of subaltern literary nationality: language which seemed to directly embody the absent condition of social rootedness recorded by the novels themselves.

There are deep ironies in Margaret Thatcher's decisive role in the political developments which led to Scottish devolution, and in the salience of her social vision in the 'new renaissance' novels. Just as contemporary Scotland is, in Andrew O'Hagan's phrase, 'a nation of conservatives who never vote Conservative' (2008, p. 24), these novels show a society quick to evince a communitarian consensus in politics, but almost devoid of the ordinary sociality which had been the 'given' substrate of novelistic realism. For all their influence (real and exaggerated) in renovating Scottish identity, there is a striking paucity of collective experience and large-scale we-ness in these books. By Benedict Anderson's model of 'imagined community', the archetypal hero 'becomes the bearer of a consciousness of the nation as interconnected space, which becomes in turn a sign of the interconnected consciousness of the "people" of whom he or she is now representative' (Craig 1999, p. 12). But with the monumental exception of Lanark, the most celebrated Scottish novels of the past three decades provide few legible co-ordinates for integrating the 
subjective, interpersonal and national in this way - they objectify no convincing space of the 'many' in which to locate the lyric-novelistic 'one'.

\section{A.L. Kennedy, Looking for the Possible Dance (1993)}

Writing in 1993, Gavin Wallace offers a thematic litany of 'a substantial majority of the most significant [Scottish] novels' published since the 1970s. Their 'constituent complaints' include:

the spiritual and material deprivations of unemployment and decaying communities; failures to find - or accept - self-fulfilment in education, work, emotional relationships; inarticulacy and alienation escaped through alcoholism; destructive mental instability; the paralysing hyper-awareness of class and cultural differentiation; crippling incapacities to give love, or to receive it. (p. 217)

With the exception of 'inarticulacy' this list could serve as a rough guide to the fiction of A.L. Kennedy, whose first novel appeared in the same year. In Looking for the Possible Dance a tormented but painfully lucid Glasgow community worker struggles in life and love under social conditions where both 'community' and 'work' seem a kind of sham. The novel's intense introversion, observational precision and temporal misdirections would later emerge as hallmarks of Kennedy's crisp prose, recognised by the Granta list of Best Young British Novelists in both 1993 and 2003.

Labelling a Scottish writer British meant something slightly different a decade later, a development partly telegraphed in the dislocations of Looking for the Possible Dance itself. Margaret Hamilton met her (Scottish) lover, Colin, while at university in England, and their relationship is dominated by his fickle migrations between London and Glasgow. The novel's complex jigsaw of memories is framed by a southbound train journey between the same cities, during which Margaret befriends a disabled man of uncertain age who shares his name with the Scottish inventor of the steam engine. James Watt is utterly dependent on others and communicates only through writing, but his wit and vitality shine through the boredom and disappointment of not directing his own life. James hates the doctors and pills, and yearns to be accepted in 
his difference: as 'FUC WON HUNNER PERCEN MEEEEEE' (p. 191). His role as the resistant passenger, probably outgrown his dependence but powerless to change it, marks him out as the iconically Scottish figure in the book. But his yearning for acceptance is quite beyond Margaret, whose selfhood seems as tenuous as her hometown.

As the book begins, Margaret is leaving a city whose actuality is constantly in doubt. Passing through the 'curiously unconvincing' urban environment, she feels 'that she has inadvertently started to be a film' (p. 9), a sensation which heightens as she reaches Glasgow Central station. 'The period wood-panelling and glass, ripped out several years ago, is slowly being replaced by imitation wood-panelling and glass' ( $p$. 10). The novel participates in the same heritage stagecraft, repeatedly offering us tidily schematised recipes for Scottishness. Item two of 'THE SCOTTISH METHOD (FOR THE PERFECTION OF CHILDREN)' declares 'the history, language and culture of Scotland do not exist. If they did, they would be of no importance and might as well not' (p. 15). It is only at university in England that Margaret discovers her nationality (Kennedy herself studied theatre at Warwick). 'The only two Scots on an English, English literature course', Margaret and Colin had formed a 'natural pair', though their Scottishness is stagily self-conscious. 'There was a formality about them that some of their fellow students found off-putting. Even drunk or stoned, they retained a strange air of propriety' (p. 38). England offers a world in which Margaret's alienation can be safely anchored in her cultural difference, and projected outside her brittle inner life. One of Colin's attractions is that 'he looked far too respectable to ever be rolling a joint. A Scottish upbringing had some good points' (ibid.). After berating a nocturnal horn-player as a 'fucking drunken English bastard', he wonders 'do you think that's me conforming to a national stereotype?' (p. 44).

The insistence with which the novel thematises its Scottishness, going out of its way to highlight and address conventional national signifiers, is one reason Looking for the Possible Dance might be read as a representative 'new renaissance' novel; another is how clearly it premises the extravagant assertion of that Scottishness on rejections of Thatcherism. Margaret graduates 'in the summer after Orwell's year', at the height of British class conflict when 'England seemed more and more like a foreign country, even to itself' (p. 38). This national estrangement is mirrored by her dislocation as a 
British political subject. Disturbed to find herself 'extremely happy' at radio reports of the IRA's Brighton bombs, 'it worried her when she stood in crowds and heard herself yelling with them, “One more cut - Thatcher's throat! One more cut Thatcher's throat!' But she yelled it' (p. 39). Colin and Margaret know the protest is futile; the theatrical objectification of their dissent - of standing for what they stand for - hints both at the emptiness of democratic culture and its free rejection. Their politics becomes a cunning 'dance' both ineffectual and aesthetically sovereign, with no significance beyond its own constituent actions: 'they had decided they lived in a country where pointless gestures were all they had left to make. There was almost a nobility in that' (ibid.).

The ennobling of 'irrelevance and defeat' (p. 40) is a key pattern in the formation of subaltern Scottishness in the 1980-90s. In the 'new renaissance' period the workless urban poor and their language are iconically nationalised: as despised remainders (or even internal enemies) within the Thatcherite narrative of self-reliance and unitary Britishness, but rhetorically central to an assertion of Scottish difference, community and authenticity. The 'possible dance' of Kennedy's title becomes the elaborated setpiece in which the values of the local working-class community - articulated via received, 'couthy' conventions of Highlandism - are shown to trump both the possessive individualism of government ideology, and the life-denying strictures of Mr Lawrence, Margaret's sinister (Scottish) boss at the community centre. The novel's climax is a charity ceilidh held on his premises, but organised by an unemployed working-class intellectual who provides a suggestive gloss on this usable (and flexible) tradition:

The purposes of the ceilidh, a uniquely unsullied flowering of Scottish culture, are many. [...] As the Israelites in slavery had their psalms, so we have the ceilidh. As the Africans transported to Haiti kept their voodoo, so we have the ceilidh. As every languageless, stateless, selfless nation has one last, twisted image of its worst and best, we have the ceilidh. Here we pretend we are Highland, pretend we have mysteries in our work, pretend we have work. We forget our record of atrocities wherever we have been made masters and become comfortable servants again. Our present and our past creep in to 
change each other and we feel angry and sad and Scottish. Perhaps we feel free. (pp. 145-6)

Adroitly re-casting the traditional Scottish celebration into a focus of protest, liberation and wry self-knowledge, Kennedy allows kitsch images of Scottishness to be refigured as vaguely postcolonial vehicles of resistance and self-assertion. Graham decorates the centre with tartan banners and 'a battered Saltire', but the walls are also adorned with 'new signs', handwritten quotations from 'Thoreau, Brecht, Paine, Thomas Muir, Cervantes' (p. 172). This selection-box of intellectual heroes forms a new, autodidact tableau of political identification, at the centre of which is the bêtenoire of postcolonial reason: the sovereignty and self-grounding of the Western subject. Graham gestures toward one of his chosen texts.

'Look over there - René Descartes. His “Second Meditation”, fucking read it. He's telling me I can be everything, the whole fucking world - telling me that I can do that. I have that inside. And I'm fed up with folk who are certain that I'm nothing but shite underfoot. Tonight, I'm backing Descartes. We all are.' (pp. 172-73)

Read on its own emancipatory terms, this unlikely slogan clearly exceeds the narrative of democratic self-actualisation on which the 'new renaissance' is premised, and comes closer to an anarchist or existential vision of freedom. This episode resonates with Alan Freeman's observation that Kennedy's fiction concerns nothing less than 'the struggle to construct and sustain the human subject in contemporary life' (1997, p. 7). Far from the autonomy of the Cartesian subject, however, Kennedy's characters are shown to lean heavily on the props and pageants of national difference. Rather than supplying the narrative context for inter-connected identity, templates of nationhood are deployed to order and stabilise the fraught selfhood of individuals. The advent of a Scottish parliament seems no more likely than the ceilidh or the community centre to alleviate the 'numberless, larger failings' (p. 24) of a society rich in identity-rituals but seemingly devoid of ordinary ethos and sociality. Several key 'new renaissance' novels radically constrain our vantage-point on the sharable public world - what Anderson calls the 'socioscape' (1991, p. 32) - and shift the figurative medium of national co-presence from narrative space to narrative voice. 


\section{James Kelman, How late it was, how late (1994)}

Kennedy's account of her beginnings as a Scottish writer echo those of Alan Warner, Janice Galloway, and many others; Alasdair Gray and Lanark, and then

Gray's work led me to [the poet] Tom Leonard and James Kelman, writers who broke the most fundamental rule of my childhood - they sounded Scottish. When I was a child, if you wanted to be successful, you had to sound anglicised or English. [...] Leonard and Kelman produced work that celebrated their right to sound like themselves and extended that courtesy to the reader. [...] You can imagine the effect of feeling that if you open your mouth you will sound wrong, that you are somehow thinking wrongly in your own head. Instilling such a feeling is one of the most fundamental ways to control a population. Now imagine what happens when the feeling stops - that miracle. (Kennedy 2011)

Pascale Casanova compares the influence of Kelman, Gray and Leonard to that of Mark Twain, insofar as their 'littérarisation of oral practices' constitutes a new national literary idiom comparable in importance to Huckleberry Finn (2007, p. 282). Both the 'miracle' and the Twain comparison are overstatements; two centuries of Scottish novelists had wrestled with the division between standard English narration and vernacular dialogue (notably James Hogg and Lewis Grassic Gibbon), but never with comparable success in establishing Scottish 'literary space'. Michael Gardiner, among other critics, equates Kelman's aesthetic validation of Glasgow working-class language with the advent of Scottish devolution: 'dissatisfied with being politically silenced in the 1980s and 1990s, [Scots] had to find a creative solution [...] Kelman's rise came at a time when Scots were literally finding a political "voice" in the form of the new Parliament' (2005, p. 155). But Kelman is a libertarian socialist who invests no hope in parliaments or political parties, and at times seems not to believe in national cultures either (Nicoll 2000). Parliamentary metaphors for his work risk distorting its radical political implications, especially in the case of How late it was, how late, the novel whose extreme particularism seems to cancel any form of 
collective belonging or identity, and to erode the sharable narrative space of the imagined community.

His strength of influence on Scottish writing has tended to obscure Kelman's place as the most formally ambitious and politically rigorous novelist working anywhere in the British Isles, and among the most acclaimed anywhere (he has twice been nominated for the Man Booker International Prize). How late it was, how late made Kelman the first (and as yet only) Scottish winner of the Booker prize. The notorious controversy surrounding the award, during which Kelman was subjected to a 'suppuration of racist, xenophobic class hatred' (Linklater 1994), has unfortunately eclipsed the novel itself, which is a landmark of subjective realism as well as a subtle reworking of Milton's Samson Agonistes (Hames 2009). Kelman's largely plotless narrative style dissolves class-based discursive hierarchies and treats vernacular Scottish language as a medium of 'literary' perception, expression and authority. He aims for an extreme degree of psychological immediacy in which the reader seems directly in contact with the texture of the protagonist's interiority. Aiming to 'obliterate the narrator' and its mediating role (McLean 1985, p. 80), Kelman's fiction seldom allows the reader to 'de-immerse' from the inward experience of the individual in order to glimpse some larger social, mythic or symbolic pattern. 'There's a difference between repping somebody and fucking being somebody', the protagonist of How late it was, how late reminds his would-be lawyer (p. 241), and Kelman's fiction refuses the structural detachment from lived experience effected by conventional third-person form. In the name of 'some 80 to 85 percent of the population [who] simply did not exist as ordinary human beings' in the English novel, reduced to 'behaviouristic activity' and dispossessed of 'thought and spiritual life' (1992, p. 82), Kelman creates a style of radically introverted fiction in which working-class experience is narrated from so deeply 'inside' the perspective of discrete individuals, the larger rhythms of majority life can seldom be heard.

In his first four novels (to 1994) Kelman subordinates 'objective' narrative discourse to the self-experience of his protagonists, who appear to seize its authority for their own self-narration (Craig 1993). The dramatic immediacy of this technique is especially effective in How late it was, how late, where the narration seems to enact rather than report the unremitting tension of the recently blinded protagonist's 
experience. In this passage Sammy Samuels is extracting himself from a confrontation inside a pub; the third-person narrator seems as much an 'extension of himself' (p. 253) as Sammy's walking stick:

Quiet voices quiet voices, he was gony have to move man he was gony have to fucking move, now, he stepped back, pushing out the door and out onto the pavement he went left, tapping as quick as he could, keeping into the wall. He hit against somebody but battered on, just to keep going, he was fine man he was okay except this feeling like any minute the wallop from behind, the blow in the back, the quick rush of air then thud, he kept going, head down, the shoulders hunched. (1994, p. 272)

Sammy is an unemployed ex-convict who wakes up on a patch of Glasgow wasteground, unaccountably assaults some undercover police officers, and is blinded soon after they take their revenge. How late it was, how late conveys, with overpowering intensity, his efforts to navigate this predicament, one compounded by the disappearance of his girlfriend and acute police interest in friends Sammy may or may not have met during a drinking binge he cannot remember. As he navigates various circles of bureaucratic hell, moving from police custody to doctors' offices to charity clinics via the state social security apparatus, Sammy encounters lawyers, fellow prisoners and his young son. But he remains utterly alone in his struggle, and insists on a personally authenticated confrontation with state power: 'He had nay intention of using a rep [lawyer]. [...] Nay cunt was gony get him out of trouble; nay cunt except himself' (p. 245).

How late it was, how late is a heroic monument to the freedom and resilience of the individual subject - if any contemporary novelist 'backs Descartes', it is Kelman but the fiction of psychological immersion he achieves is largely divorced from recognisable Scottish society. Traces of contemporary Glasgow are few and cursory, with the important exception of language - the medium of this characters' psychic being, mobilised as a literary device which seems to embody rather than signify social rootedness. In 'obliterating' the universalist third-person narrative space from which his characters might formerly have been 'fixed' as objects - their lives and speech rendered as mere sociological facts by an external, 'colonising' standard English 
narrator - Kelman's narrative experiments severely attenuate the 'interconnected' spatiality of the national imaginary. His narrative experiments aim to realise subjectivity rather than nationality, and his influence on the contemporary novel is not confined to Scotland (Akbar 2011).

\section{Irvine Welsh, Trainspotting (1993)}

In a prescient essay of 1992 marking the centenary of Hugh MacDiarmid, Robert Alan Jamieson noted the post-Kelman vogue with some trepidation. (Kelman's breakthrough novel, The Busconductor Hines, had appeared in 1984.)

Glasgow's rebirth, and the establishment of a literature of the people of urban Scotland, is unquestionably a vital component in the making of a greater, contemporary, wholly Scottish literature. But $[\ldots]$ there is a danger that the curse of success, imitation, of which there is already much evidence, may lead to an urban kailyard of inverted values, where the pub and the bookie's replace the school and the kirk, where the breakdown of family and community becomes as much a cipher for the state of Scottish society in the 1990s as the fictional perpetuation of the same was a cipher for the Kailyarders a hundred or so years ago, long after the passing of the world they described into unreality. (p. 5)

It was a frenetically hyper-realist novel from Edinburgh, published only a few months after Jamieson's essay, which cemented the pattern he feared. But Trainspotting contains no elegy for family and community of the kind suggested by 'urban kailyard'. Its individualism is just as romantic as that of How late it was, how lateWelsh's surrogate, Mark Renton, even makes a speech in court declaring his allegiance to Kierkegaard - but the 'NUMERO FUCKING UNO' freedoms with which Trainspotting is ultimately concerned owe more to postmodernism than Kelman's existentialism (p. 30). This profoundly and entertainingly amoral novel ridicules every ethical narrative, including that of national liberation and renewal.

Renton admits that the philosophy of choice and subjective truth 'seek[s] to undermine collective societal wisdom' (p. 166), a pattern reflected in the narrative 
architecture of Trainspotting, which does not so much integrate as aggregate stridently first-person episodes from the lives of a loose grouping of friends acquainted through the common pursuit of private (chemical) pleasures. Welsh's grotesquerie trades in heightened, lacerating details, though the novel's more banal and anecdotal dimension - banter about television, football, weekend hedonism - is arguably closer to ordinary Scottish experience than the tense and surreal meditations of Kennedy or Kelman. Trainspotting's influence and critical interest has centred on its use of demotic Scots in a style of fiction neither realist nor sentimental, but calculated to shock and exhilarate. The global success of this self-exoticism is one reason to hesitate before viewing the Trainspotting phenomenon within strictly national horizons. Given its overt hostility to the optimism of the 'new renaissance' the central character Renton declares the Scots 'the most wretched, servile, miserable, pathetic trash that was ever shat into creation' (p. 78) - it seems perverse to present Welsh's debut novel as an expression of neo-national feeling. Even its direct commentary on the demise of Britishness vigorously eschews any affirmation of Scottishness:

The pub sign is a new one, but its message is old. The Britannia. Rule Britannia. Ah've never felt British, because ah'm not. It's ugly and artificial. Ah've never really felt Scottish either, though. Scotland the brave, ma erse; Scotland the shitein cunt. We'd throttle the life oot ay each other fir the privilege ay rimmin some English aristocrat's piles. Ah've never felt a fuckin thing aboot countries, other than total disgust. (1993, p. 228)

Trainspotting undoubtedly is, however, a major landmark in the promotion of a hip 'postcolonial' (and perhaps post-political) vision of Scottish selfhood, articulated within an idiom of angry, undeceived marginality which will countenance no belief in any alternative to atomised subcultures defined by style, attitude and consumption. For Berthold Schoene, its great achievement

resides in its re-authentication of the Scottish tradition, paradoxically achieved by breaking with it, by asserting a local rootedness marred by deracination, and by instilling a sense of flux and mobility from claustrophobic stagnation. (Schoene 2010, p. 1) 
Trainspotting explodes tartan fantasies of Scottishness, but does not settle on any reality principle available to novelistic identification. Here Renton vividly recalls the displacements of a working-class 'schemie' traversing the postcard vistas of central Edinburgh, unable to inhabit thoroughly alienated and appropriated space:

They say you have to live in a place to know it, but you have to come fresh tae it tae really see it. Ah remember walkin along Princes Street wi Spud, we both hate walkin along that hideous street, deadened by tourists and shoppers, the twin curses ay modern capitalism. Ah looked up at the castle and thought, it's just another building tae us. It registers in oor heids just like the British Home Stores or Virgin Records. We were heading tae these places oan a shoplifting spree. (1993, p. 228)

This dichotomy of 'seeing' and 'knowing', in which only the first has any impact or meaning, should alert us to the novel's complicity with the forces of consumerism it frequently castigates. Robert Morace argues that 'Trainspotting had originally been written against the grain of the mainstream culture of spectacle which swiftly coopted it' (2007, p. 227), but the novel is locked into a consumerist circuit of desire and display from the start, registering in its sensibility the pre-conceived taste of the Virgin Records stores in which it would eventually appear (and frequently be stolen). Trainspotting is a novel of postmodern self-fashioning trading on the signs and languages of pre-modern communal rootedness, and the only mode of 'authentication' it leaves standing is that of consumerism itself. 'Buying into' the various performed identities of the novel seems the only way to engage with its savage and seductive anger.

Mediated and vectored to a global audience by Danny Boyle's 1996 film,

Trainspotting has become not only a cutting-edge brand signifier for a fetishised, cool version of working-class drug culture, but also the most widely globalised representation of contemporary Scottishness. As a result, the particular linguistic code developed by Welsh to articulate the experiential reality of a certain community in a certain part of Edinburgh has become 
standardised as the authentic Scottish voice, both celebrated by the media and eagerly emulated by Welsh's peers and successors. (Innes 2010, p. 301)

James Kelman had laid the foundation for this nationalisation of class idiom, but Welsh deploys it to ends quite remote from Kelman's politics of narrative. The language games in which the characters of Trainspotting are immersed belong to a postmodern economy of difference - verbal identity is a commodity to be produced, exchanged and discarded in order to realise personal benefits. The vernacular language used to signify some real, residual or potential condition of communal rootedness in the Scottish novels of a previous generation (e.g. McIlvanney 1987 [1975]) is exploited in Trainspotting as a reservoir of subcultural 'grittiness' suited to an international appetite for edgy minoritarian hipness. 'Much the most important thing about language', writes Anderson, 'is its capacity for generating imagined communities, building in effect particular solidarities' (1991, p. 133). But when, as in Trainspotting, these solidarities are reduced to badges of stylistic attachment - the verbal equivalent of an Iggy Pop T-shirt - and realised in isolation from any narrative context or sharable social space in which they might be mobilised into collective action or experience, their political valence alters accordingly. The excited particles of Trainspotting's swirling polyphony belong ultimately to an order of stylised selfdisplay:

The Bridges is hotchin wi minge. Ooh, ooh la la, let's go dancin, ooh, ooh la la, Simon dancin ... There is fanny of every race, colour, creed and nationality present. Oh ya cunt, ye! It's time tae move. Two oriental types consulting a map. Simone express, that'll do nicely. Fuck Rents, he's a doss bastard, totally US.

— Can I help you? Where are you headed? ah ask. Good old-fashioned Scoattish hoshpitality, aye, ye cannae beat it, shays the young Sean Connery, the new Bond, cause girls, this is the new bondage...

- We're looking for the Royal Mile, a posh, English-colonial voice answers back in ma face. What a fucking wee pump-up-the-knickers $\mathrm{n}$ aw. Simple Simon sais, put your hands on your feet... (1993, p. 29) 
The impact and popularity of the novel has much to do with the intensity of its vocal kineticism, the rush of its textual foreignness getting exhilaratingly 'in the face' of the reader. In this sense Trainspotting might easily be seen as a postmodern compendium of striking verbal and political poses, part of a cinematic idiom of dazzling gestures even before its transfer to the screen. Just as the novel's opportunistic hero has internalised the Thatcherite entrepreneurialism he rails against, the novel's exploitation of vernacular forms fits comfortably within a consumerist logic of commoditised difference (but see also Kelly 2005, pp. 66-74).

\section{Conclusion: No Yir Ain}

For Ian A. Bell, the unifying dynamic of 'new renaissance' fiction is not a struggle for national collectivity but for personhood:

Refusing to collaborate with a transcendental, totalising and finally determining sense of national identity, Scottish novelists since the 1980s have concentrated instead on individual moments of crisis, alienation and fragmentation, moments dramatising the loss and discovery of self, as they are articulated through the lives of some of those conventionally excluded from the story of Scotland. (Bell 1996, p. 226)

Viewed in retrospect, many of the 'new renaissance' novels centre on 'marginal' figures of this kind, re-coded as central to a new idiom of national subalternity combining the demand for autonomy with the recognition of difference.

That these novels seldom turn their gaze toward the ambient collective world in which ordinary, anonymous urban life mainly unfolds complicates any effort to present them as continuing a Scottish novelistic tradition defined by 'the moral primacy of community' (Hart 1978, p. 401). Despite the comforting story of modern Scotland's communal rejection of Thatcherism, the 'new renaissance' novels broach collective identity primarily to address more fundamental and intractable ethical dilemmas centred on the individual. Even the romantic Highlandism of the ceilidh in Looking for the Possible Dance is primarily a convenient cultural language for mediating a fundamental projection of 'self' onto 'world' - an equation central to Kelman's vernacular art. The most disenchanted and consciously stylised personae in this 
fiction tend to insist on their sovereign self-presence - on a possessive 'being' anterior to its cultural 'repping' and display. Mark Renton reads Carl Rogers' On Becoming a Person as part of his court-mandated drug treatment, but resists being constituted as a 'case' to be narrated and explained by others: 'Then yir theirs, no yir ain' (p. 187). Perhaps this is the slogan of autonomy on which to conclude. This chapter has unavoidably tethered these Scottish novels to a discourse of literary nationalism which constitutes them as artefacts of national 'repping' and renewal, but Renton's resistance to diagnostic appropriation - even for the larger purpose of his own empowerment - applies quite as forcefully to the metanarrative of the "new renaissance'.

In one sense, the historical truth-value of that despairing and optimistic story is determined by the result of the 2014 referendum on independence - that is, by the aggregate behaviour of ordinary Scottish people, so notably scarce in novels held to release and renovate their historic 'identity', while furnishing scant means of mapping their large-scale commonality in the here and now. Given that Scottish voters have for now, and perhaps only for now - spoilt the narrative arc implied by 'new renaissance', it has become all the more important (and perhaps less difficult) to read these novels as works of fiction and invention, rather than 'real' ciphers and expedients of recovered nationality. ${ }^{4}$

\section{BIBLIOGRAPHY OF WORKS CITED}

\section{Primary}

Gibbon, Lewis Grassic (2006 [1932-4]), A Scots Quair [Sunset Song, Cloud Howe, Grey Granite] (Edinburgh: Polygon)

Gray, Alasdair (2007 [1981]), Lanark: A Life in Four Books (Edinburgh: Canongate)

Kelman, James (1994a), How late it was, how late (London: Secker and Warburg) Kennedy, A.L. (2005 [1993]), Looking for the Possible Dance (London: Vintage) McIlvanney, William (1987 [1975]), Docherty (London: Sceptre)

\footnotetext{
${ }^{4}$ The argument of this chapter is more fully developed in Hames 2013, which beat it into print.
} 
Morgan, Edwin (1994), Sweeping Out the Dark (Manchester: Carcanet)

Welsh, Irvine (1993), Trainspotting (London: Secker and Warburg)

Secondary

Akbar, Arifa (2011), 'Sounds of the street: How authors are turning to slang narratives as a more authentic mode of storytelling', The Independent, 4 March.

Anderson, Benedict (1991), Imagined Communities: Reflections on the Origin and Spread of Nationalism, Rev. Edn. (London: Verso)

Bell, Ian A. (1996), 'Imagine Living There: Form and Ideology in Contemporary Scottish Fiction' in Studies in Scottish Fiction: 1945 to the Present, ed. Suzanne Hagemann (Frankfurt: Peter Lang), pp. 217-233.

Beveridge, Craig and Ronald Turnbull (1989), The Eclipse of Scottish Culture: Inferiorism and the Intellectuals (Edinburgh: Polygon)

Casanova, Pascale (2007), The World Republic of Letters, trans. M. B. DeBevoise (Cambridge, MA: Harvard University Press)

Craig, Cairns (1993), 'Resisting Arrest: James Kelman' in The Scottish Novel Since the Seventies, ed. Gavin Wallace and Randall Stevenson (Edinburgh: Edinburgh University Press), pp. 99-114.

----- (1999), The Modern Scottish Novel: Narrative and the National Imagination (Edinburgh: Edinburgh University Press)

----- (2003), 'Scotland: Culture After Devolution' in Ireland (Ulster) Scotland: Concepts, Contexts, Comparisons, ed. Edna Longley, Eamonn Hughes and Des O’Rawe (Belfast: Cló Ollscoil na Banríona), pp. 39-49. ----- (2007), 'The Study of Scottish Literature' in The Edinburgh History of Scottish Literature, Vol. I (From Columba to the Union), ed. Thomas Owen Clancy and Murray Pittock (Edinburgh: Edinburgh University Press), pp. 16-32.

Culler, Jonathan (1999), 'Anderson and the Novel', Diacritics 29.4, pp. 19-39. Ferrebe, Alice (2010), 'Welsh and Tradition' in The Edinburgh Companion to Irvine Welsh (Edinburgh: Edinburgh University Press), pp. 9-18.

Freeman, Alan (1997), 'Realism Fucking Realism: The Word on the Street - Kelman, Kennedy and Welsh', Cencrastus 57, pp. 6-7. 
Gardiner, Michael (2005), Modern Scottish Culture (Edinburgh: Edinburgh University Press)

Gifford, Douglas (1990a), 'At Last - the Real Scottish Literary Renaissance?', Books in Scotland 34, pp. 1-4.

----- (1990b), 'Killing the Dreams of Tradition and Modernity', Books in Scotland 34, pp. 10-18.

----- (2007), 'Breaking Boundaries: From Modern to Contemporary in Scottish Fiction' in The Edinburgh History of Scottish Literature, Vol III: Modern Transformations, New Identities (from 1918), ed. Ian Brown (Edinburgh: Edinburgh University Press), pp. 237-52.

Gray, Alasdair (1992), Why Scots Should Rule Scotland (Edinburgh: Canongate) Hames, Scott (2009), 'Eyeless in Glasgow: James Kelman's Existential Milton', Contemporary Literature 50.3, pp. 496-527.

----- (2010), 'Kelman's Art-Speech' in The Edinburgh Companion to James Kelman, ed. Scott Hames (Edinburgh: Edinburgh University Press), pp. 86-98.

----- (2012), ed., Unstated: Writers on Scottish Education (Edinburgh: Word Power)

----- (2013), 'On Vernacular Scottishness and its Limits: Devolution and the Spectacle of "Voice", Studies in Scottish Literature 39.1, pp. 201-222.

Innes, Kirstin (2010), 'Mark Renton's Bairns: Identity and Language in the PostTrainspotting Novel' in The Edinburgh Companion to Contemporary Scottish Literature, ed. Berthold Schoene (Edinburgh: Edinburgh University Press), pp. 301-309.

Hart, Francis Russell (1978), The Scottish Novel: A Critical Survey (London: John Murray)

Jamieson, Robert Alan (1992), 'MacDiarmid's Spirit Burns On', Chapman 69-70, pp. 3-9.

Kelly, Aaron (2005), Irvine Welsh (Manchester, Manchester University Press)

----- (2007), 'James Kelman and the Deterritorialisation of Power' in The Edinburgh

Companion to Contemporary Scottish Literature, ed. Berthold Schoene (Edinburgh: Edinburgh University Press), pp. 175-83.

Kelman, James (1992), 'The Importance of Glasgow in My Work' in Some Recent Attacks: Essays Cultural and Political (Stirling: AK Press), pp. 78-84. ----- (1994b), 'Elitist slurs are racism by another name', Scotland on Sunday, 16 October. [Booker Prize acceptance speech.] 
Kennedy, A.L. (1995), 'Not changing the world' in Peripheral Visions: Images of Nationhood in Contemporary British Fiction, ed. Ian A. Bell (Cardiff:

University of Wales Press), pp. 100-102.

----- (2011), 'Scotland's cultural awakening is a terrifying prospect for politicians', The Guardian, 9 October.

Linklater, John (1994), 'RLS Posted and Gladstone Bagged', Glasgow Herald, 24 December.

MacDiarmid, Hugh (1968 [1946]), “'Lewis Grassic Gibbon”- James Leslie Mitchell' in The Uncanny Scot, ed. Kenneth Buthlay (London: MacGibbon and Kee, 1968), pp. 154-63.

McIlvanney, Liam (2002), 'The Politics of Narrative in the Post-War Scottish Novel' in On Modern British Fiction, ed. Zachary Leader (Oxford: Oxford University Press), pp. 181-208.

McLean, Duncan (1985), 'James Kelman Interviewed', Edinburgh Review 71, pp. 6480.

Morace, Robert (2007), 'Irvine Welsh: Parochialism, Pornography and Globalisation' in The Edinburgh Companion to Contemporary Scottish Literature, ed. Berthold Schoene (Edinburgh: Edinburgh University Press), pp. 227-235.

Morgan, Edwin (1974), 'The Beatnik in the Kailyard' [1962] in Essays (Cheadle: Carcanet New Press), pp. 166-176.

Nairn, Tom (2007), Faces of Nationalism: Janus Revisited (London: Verso)

Nicoll, Laurence (2000), “This is not a nationalist position”: James Kelman’s Existential Voice', Edinburgh Review 103, pp. 79-84.

---- (2010), 'Kelman and the Existentialists' in The Edinburgh Companion to James Kelman, ed. Scott Hames (Edinburgh: Edinburgh University Press), pp. 12130.

O'Hagan, Andrew (2008), 'Scotland's Old Injury' in The Atlantic Ocean: Essays on Britain and America (London: Faber), pp. 19-30.

Schoene, Bertold (2010), 'Introduction' in The Edinburgh Companion to Irvine Welsh (Edinburgh: Edinburgh University Press), pp. 1-8.

Speirs, John (1962), The Scots Literary Tradition: An Essay in Criticism, 2nd edn. (London: Faber) 
Thomson, Alex (2007), "YYou can't get there from here": Devolution and Scottish literary history', International Journal of Scottish Literature 3

[www.ijsl.stir.ac.uk]

Wallace, Gavin (1993), 'Voices in an Empty House: The Novel of Damaged Identity' in The Scottish Novel Since the Seventies, ed. Gavin Wallace and Randall Stevenson (Edinburgh: Edinburgh University Press), pp. 217-31.

Warner, Alan (2011), 'Out of Oban: The SRB Interview', Scottish Review of Books 7.3, pp. 12-13.

Watt, Ian (1987 [1957]), The Rise of the Novel: Studies in Defoe, Richardson and Fielding (London: Hogarth)

Whyte, Christopher (1998), 'Masculinities in Contemporary Scottish Fiction', Forum for Modern Language Studies 34(2), pp. 274-85. 